\title{
A PSZICHOLÓGIAI SZERZŐDÉS SZAKIRODALMI ÖSSZEFOGLALÓJA
}

\author{
A LITERATURE SUMMARY \\ OF PSYCHOLOGICAL CONTRACT
}

A szervezeti kutatások területén népszerű téma a munkaadó és a munkavállaló kapcsolatának vizsgálata. Ezt a kapcsolatot a pszichológiai szerződés konstruktum és fogalomrendszerével megalkotott elméletekkel is kutatják. A szerző a tanulmányban a pszichológiai szerződést és központi témáit mutatja be. Kísérletet tesz arra, hogy társadalmi szintű relevanciájára rámutasson, és egzaktabb mérési eljárásokat javasoljon. A tanulmány elméleti összefoglaló. Célja, hogy a magyar nyelvű szakirodalomban bemutassa a pszichológiai szerződést. A legtöbbet hivatkozott munkák bemutatását követően a fókusz a konstruktumra reflektáló módszertani észrevételek áttekintésén volt. A konstruktum és az elméletek a pszichológiai hangsúly mellett szociálpszichológiai és szociológiai aspketusból megközelíthetők. A paradoxont hordozó fogalom kontextuálisan feloldható. Az alkalmazhatósághoz javasolt elmélet a kötődéselmélet. A pszichológiai szerződés konstruktum és elméletek megértésével, felülvizsgálatával egzaktabb kutatási design-ok tervezhetők így javítva az eredmények validitását. Ha így születnek komparatív tanulmányok, a konstruktum standardizálhatóvá válhat.

\section{Kulcsszavak: pszichológiai szerződés, munkaadó-munkavállaló kapcsolat, munkaszerződés}

In organisational research, examining the employer-employee relationship is a popular subject. The relationship is also explored with the psychological contract theory. The author presents a theory with its central themes and places it within a social perspective to suggest a more exact measure. The study is a theoretical summary. Its aim is to introduce and present the theory in the Hungarian literature. Presenting the most cited works, the focus is on a review of methodological views reflecting on the construct. The construct and its theories can be approached by social, psychological, and sociological aspects, in which we emphasise the psychological one. The construct bearing paradox can be resolved. For application, attachment theory is recommended. By understanding and reviewing the theory, more exact research designs can be planned improving the validity of results. If comparative studies can be built by it, a standard measure of the construct would be possible.

Keywords: psychological contract, employer-employee relationship, workcontract

\section{Finanszírozás/Funding:}

A szerző a tanulmány elkészítésével összefüggésben nem részesült pályázati vagy intézményi támogatásban.

The author did not receive any grant or institutional support in relation with the preparation of the study.

\section{Szerző/Author:}

Gubányi Mónika, doktorjelölt, Semmelweis Egyetem, (gubanyi.monika@gmail.com)

A cikk beérkezett: 2020. 07. 13-án, javítva: 2020. 08. 27-én, elfogadva: 2020. 09. 04-én.

This article was received: 13. 07. 2020, revised: 27. 08. 2020, accepted: 04. 09. 2020.

A szerző munkavállaló és munkaadó kapcsolatának (employer-employee relationship) vizsgálatához leírt pszichológiai szerződés (psychological contract) konstruktum definiálási kísérleteit és konceptuális rendszerét foglalja össze, alternatív mérési eljárást ajánl, és reflektál a pszichológiai szerződéssel vizsgált jelenségre.
A pszichológiai szerződés konstuktum a munka- és szervezetpszichológiához tartozik. A munka- és szervezetpszichológia területén belül a humánerőforrás-menedzsment gyakorlatokhoz társított elmélet (Rousseau, 1989). A felettes-beosztott munkaviszonyban a kapcsolatot befolyásoló pszichológiai tartalmak értelmezésére és vizsgálatára írták le (Argyris, 1960). A témában íródott 
magyar szakirodalmak olyan kapcsolati dinamikák magyarázatához alkalmazták, mint szervezeti bizalom, vezetői bizalom, edző-tanítvány kapcsolatának teljesítményre gyakorolt hatása (pl. Heidrich, 2013). A magyar nyelvü szakirodalomban nincs jelen a pszichológiai szerződés áttekintő tanulmányozása, sem összefoglalása vagy értelmezése a bőséges nemzetközi kutatási eredmények ellenére (Coyle-Shapiro, Costa, Doden \& Chang, 2019). Az elmélet átfedéseket mutat a pszichológus-kliens együttmüködéséhez munkakeretet adó szerződéssel, ezért ennek tisztázásához terápiás elméleteket mutat be (Levinson, Price, Munden, Mandl \& Solley, 1962). A szerző kitérhetne a társadalmi és pszichológiai szerződés különbségeire is, de a terjedelmi korlátok miatt ettől eltekint (Jardat, 2012). Terápiás kontextusban Menninger (1958) vezette be a fogalmat mint pszichoterápiás szerződés, hogy átláthatóvá tegye a terápiás kezelést, amit tranzakcionális jellegéből adódóan szerződésnek tekintett. Ennek értelmében a megfelelö képesítéssel rendelkező terapeuta szolgáltatást nyújt a páciensnek, aki ezt önként elfogadja. Menninger három pontban különböztette meg a pszichoterápiás szerződést más szerződésektől. Míg kereskedelmi tranzakciónál a cél az üzlet nyélbe ütése attól függetlenül, hogy a felek mit éreznek egymás iránt, továbbá az üzleti tranzakciók minden esetben határidöhöz kötöttek, a pszichoterápiás szerződésben a kapcsolat nem eszköz a tranzakcióhoz, hanem maga a terápia célja a kapcsolódás a pácienssel és a páciensért. Noha a terápiás folyamatot a terapeutának is le kell zárnia, céljából következően a páciens életére nézve nyitott végü. Másrészről az üzleti szerződés két félre tartozik, a pszichoterápiás kapcsolatban viszont megjelenhetnek a páciens életében fontos személyek áttétel formájában. Berne (1966) különbséget tett a magánpraxisban és az intézményben dolgozó pszichoterapeuták szakmai munkájának keretéül szolgáló szerződések között. Intézményben dolgozó terapeuta munkájában fa eladatai szerint négy szinten működtetett szerződés érhető tetten. Az adminisztratív szerződés tisztázza a projekt- vagy intézményi célokat, és tartalmazza az intézmény müködését szabályozó törvényeket, intézményi szabályokat. A professzionális szerződés a dolgozók szakmai céljait írja le. A pszichológiai szerződés a terapeuta és szupervízorainak, feletteseinek, kollégáinak a személyes szükségleteit, a szervezet és a szervezet által alkalmazott módszerek szükségleteit, az intézményi és az intézmény határain túli hierarchiából adódó hatásokat foglalja magába, mint amilyen a kultúra, szakmai tekintélyek, fönökök, intézmények, intézményi szabályozók. A konkrét terapeuta-páciens szerződést a fentiek értelmében határozza meg. A magánpraxisban dolgozóknál is beszélhetünk intézményi keretekröl, ha a terapeuta szakmai egyesülethez tartozik.

\section{A pszichológiai szerződés}

\section{Fejlődéstörténet}

A pszichológiai szerződés elsőként szervezeti kapcsolatokat vizsgáló kutatásokban az 1960-as években jelent meg a munkavállaló és munkaadó kapcsolatának alakulására ható és a munkaszerződésben megfogalma- zott tartalmakon túlmutató pszichés tényezők leírására (Argyris, 1960). A pszichológiai szerződés elmélettel dolgozó, kurrens szakirodalmak Argyris (1960), Levinson et al. (1962), valamint Schein (1965) munkáit idézik, mint a témában íródott kezdeti kutatásokat (Coyle-Shapiro et al., 2019). Argyris (1960) pszichológiai munkaszerződésnek ( ssychological work contract) nevezte azt a munkaadó és munkavállaló közti foglalkoztatási viszonyt, amelynek célja a munkaszerződés folytatólagosságának biztosítása. A munkaadó megérti a munkavállaló elvárásait munkamód, fizetés, biztonság és munkaadói bánásmód tekintetében, de elvárja a munkavállalótól, hogy pontosan végezze a munkáját. A kapcsolat kimondottan a munka haladásának biztosítására korlátozódik, ahol mélyebb intimitásnak nem lehet helye. A munkaszerződés pszichológiai jellege a felek elvárásainak megértésére mint egyfajta humánerőforrás-menedzsment gyakorlatra vonatkozik. Ez az elmélet a szervezetfejlesztésen belül a vezetöképzés kiaknázatlan lehetőségeire hívta fel a figyelmet. Levinson et al. (1962) 874 amerikai munkavállalóval készült interjúk elemzésének eredményei alapján alkottak elméletet. Elméletükre jelentős hatást gyakoroltak az ego-pszichológia eredményei, Menninger (1958) kötete és a Menninger Foundation kiadványa (1954) a munkavállalók mentálhigiénéjének felméréséről. Elsőként definiálták a jelenséget pszichológiai szerződésként. A pszichológiai jelző alatt a munkaadó és munkavállaló kölcsönös, de nem leírt, implicit, szóban ki nem fejezett elvárásait értették. Schein (1965) definíciója elvárások, kötelezettségek, privilégiumok, jogok a szervezet és a munkavállaló közti kapcsolatban. Az elvárások összeilleszthetőségét emelte ki a pszichológiai szerződés kulcselemeként, a szervezeti kultúrát jelölte meg feltételeként. A szervezeti kultúra alapvető előfeltevések rendszere, amelyet egy adott csoport fejleszt ki egy tanulási folyamatban, amelyben külső adaptációs és belső integrációs problémáira keresi a megoldást. Ha a problémákra adott megoldások jól működnek, érvényesnek tekintik őket, mint adekvát, belső térképnek tekinthető mentális és stabil érzelmi válaszokat (Schein, 1985). A szervezeti kultúrának van egy implicit (értékek, ideológiák, premisszák) és egy explicit (megfigyelhető, tárgyiasult elemek) szintje. Schein (1988) a pszichológiai szerződés legfontosabb alakítójának tekintette a munkahelyi szervezettel járó tekintélyrendszerhez füződő viszonyt. A pszichológiai szerződésre tekinthetünk viselkedéses drive-ként is, ha tartalmát meghatározza a szervezeti szerep, a hierarchikus viszonyokban betöltött szerep, a munkához kapcsolódó motiváció, a munkahelyi teljesítmény, az indukció, a szocializáció, a munkahelyi kapcsolatok, a karriertervek. Mindez az újra tárgyalt munkaszerződés fényében dinamikusan változhat.

Gibson (1966) összefüggésbe hozta a személyzet munkahelyi hiányzásait a munkakörökben meghatározott feladatvégzéssel. A munkakörrel járó felelősség mentén magas és alacsony bizalmi szintre sorolható pszichológiai szerződéseket (high/low psychological contract) állapított meg, amelyek alkalmazhatók a munkavállalói motiváció 
A pszichológiai szerződés konstruktum kezdeti kutatásokban megjelenő definíciói

\begin{tabular}{|c|c|c|c|c|c|}
\hline Szerző & Elnevezés & Értelmezési szint & Megközelítés & Módszertan & Definíció \\
\hline $\begin{array}{l}\text { Argyris } \\
(1960)\end{array}$ & $\begin{array}{l}\text { pszichológiai munka- } \\
\text { szerződés }\end{array}$ & diádikus & empíria & interjú & $\begin{array}{l}\text { Munkavállaló és munkaadó } \\
\text { kölcsönösen megérti, elfogadja } \\
\text { az írásba foglalt és informális } \\
\text { munkakapcsolat aspektusait. }\end{array}$ \\
\hline $\begin{array}{l}\text { Levinson et } \\
\text { al. }(1962)\end{array}$ & pszichológiai szerződés & diádikus & empíria & interjú & $\begin{array}{l}\text { Munkaadó és munkavállaló köl- } \\
\text { csönös, implicit, verbalizálatlan } \\
\text { elvárásai a munkakapcsolatban. }\end{array}$ \\
\hline $\begin{array}{l}\text { Schein } \\
(1965)\end{array}$ & pszichológiai szerződés & egyéni & elméleti & $\begin{array}{l}\text { szakirodalmi } \\
\text { feldolgozás }\end{array}$ & $\begin{array}{l}\text { Elvárások, kötelességek, privi- } \\
\text { légiumok, jogok munkahely és } \\
\text { munkavállaló között. }\end{array}$ \\
\hline $\begin{array}{l}\text { Gibson } \\
(1966)\end{array}$ & pszichológiai szerződés & rendszer & elméleti & $\begin{array}{l}\text { szakirodalmi } \\
\text { feldolgozás }\end{array}$ & $\begin{array}{l}\text { A munkavállaló-munkaadó } \\
\text { kapcsolat informális és formális } \\
\text { elemei. }\end{array}$ \\
\hline Kotter (1973) & pszichológiai szerződés & egyéni & empíria & esettanulmány & $\begin{array}{l}\text { Implicit, íratlan és formális mun- } \\
\text { kavállalói elvárások. }\end{array}$ \\
\hline $\begin{array}{l}\text { Portwood \& } \\
\text { Miller (1976) }\end{array}$ & pszichológiai szerződés & diádikus & empíria & kérdöív & $\begin{array}{l}\text { Munkavállalók kapcsolata a } \\
\text { munkahellyel komparatív fo- } \\
\text { lyamatban alakul a személyes } \\
\text { tapasztalatok és a szervezeti } \\
\text { kondíciók mentén. }\end{array}$ \\
\hline Weick (1979) & implicit szerződés & egyéni & elméleti & $\begin{array}{l}\text { szakirodalmi } \\
\text { feldolgozás }\end{array}$ & $\begin{array}{l}\text { Munkavállalói motivációk és } \\
\text { munkahelyi tapasztalatok ala- } \\
\text { kítják. }\end{array}$ \\
\hline $\begin{array}{l}\text { Nicholson \& } \\
\text { Johns (1985) }\end{array}$ & pszichológiai szerződés & rendszer & empíria & kérdöív & $\begin{array}{l}\text { A munkaszerződés befolyásolja } \\
\text { a pszichológiai szerződés tartal- } \\
\text { mát. A szervezeti kultúra átadá- } \\
\text { sának eszköze. }\end{array}$ \\
\hline Baker (1985) & pszichológiai szerződés & diádikus & empíria & kérdöív & $\begin{array}{l}\text { A munkavállaló és a munkaadó } \\
\text { leírt, leíratlan, kimondott, ki- } \\
\text { mondatlan elvárásai a kapcsola- } \\
\text { tukban. }\end{array}$ \\
\hline $\begin{array}{l}\text { Schein } \\
(1988)\end{array}$ & pszichológiai szerződés & rendszer & elméleti & $\begin{array}{l}\text { szakirodalmi } \\
\text { feldolgozás }\end{array}$ & $\begin{array}{l}\text { Munkahely és munkavállaló } \\
\text { cirkulárisan alakítja a megírt és } \\
\text { megíratlan elvárásait. }\end{array}$ \\
\hline
\end{tabular}

Forrás: saját szerkesztés

felméréséhez is. Társadalomelméleti megközelítése a pszichológiai szerződést a társadalmi integrációs folyamatok eredményének felfogható munkaszerződésből vezeti le. Megállapításait az összetartozó fogalomrendszerek értelmezésével ismertette. Érvelése szerint a munkavállalóra a szervezetben szükségletek rendszere hat, amely az emberi természetből és a kultúra felépítéséből fakad. A szükségletrendszer részeit három különállóan működő rendszer, a hiedelemrendszer, az értékrendszer, a hiedelem-értékrendszer alkotja, és ezek határozzák meg az emberi viselkedést. A hiedelemrendszerhez tartozó elvárásokat a kognitív feltételezések eredménye, elörejelzések, kognitív összefüggések összessége eredményezi. Az értékrendszer a prioritásokból és a preferenciákból tevődik össze. A szükséglet prioritását a realizálásához elérhető eszközök is alakítják. A hiedelemrendszer és az értékrendszer kölcsönösen hatnak a viselkedésre abban a tekintetben, hogy milyen vágyott és lehetséges cél vezérli a munkaadót és a munkavállalót, és a cél eléréséhez milyen vágyott és lehet- séges eszközeik vannak. Ez azt jelenti, hogy a munkával kapcsolatos döntések a hiedelem-értékrendszer müködését tükrözik, és ez eredményezi a munkavállaló identifikációját. A munkavállaló hiedelem-értékrendszerét a munkahely céljai és eszközei is befolyásolják, mint amilyen a szabályozók, a törvények, a charták és a szerződések. A munkahely hiedelem-értékrendszeréböl következik a kötelezettségek és jutalmak rendszere, amely összeköti a munkavállaló szükségleteit kielégítő tevékenységét és a munkahely célorientált tevékenységét. A munkahelyi kötelezettségek-jutalmak rendszerét építi fel a szervezeti munkamegosztás, a szervezeti szabályok differenciálódása, a munkakörök specializálódása és a pozíciók után járó jutalmazás. Mindez cserefolyamatban valósul meg (Blau, 1964). A munkaadó-munkavállaló közt létrejövő cserét a munkaszerződés legitimizálja. Gibson Maine (1906) munkáját idézi a szerződés hagyományának fejlődéséről. Maine verbális, literális, valódi és konszenzusos szerződésről ír. Ezek közül a munkaszerződés valódi szerződés, 
ami morális elkötelezettséget szentesített eredendően. A munkaszerződés nemcsak a munkahelyhez köti a munkavállalót, hanem a társadalomhoz is. Fejlödéstörténete is rámutat, hogy a munkaszerződés a társadalmi integrációs folyamatok eredményeként jött létre. A Gibson-féle pszichológiai szerződés főbb tartalmait a munkaidentifikáció, a foglalkozás státusza, a munkavállaló kora, a munkaszerződés hossza, a munkahely mérete, a munkahely nemzetközi vagy lokális jellege és a munkaadó-munkavállaló kapcsolat hitelessége alakítja ki. Nicholson és Johns (1985) a pszichológiai szerződéseket a szervezet vertikális (bizalom) és horizontális (szervezeti kultúra) integrációja mentén csoportosították diádikus foglalkoztatási viszonyként írva le azokat. A dependens foglalkoztatási viszony hierarchizáltan szervezett rendszerekben jellemző, ahol a pozíciók és a felelősségi körök mindenki számára jól körülhatároltak, ugyanakkor a laterális kapcsolatok ritkák, ami nem tesz lehetővé megfelelő információáramlást a szervezetben. Ez a fajta paternalista és tekintélyelvü munkaszerveződés az ipari fejlődés korai szakaszaiban volt jellemző. A morális foglalkoztatási viszony esetében a szervezeti kultúra homogén jellegü, amely erősíti a kohezív kapcsolatok kialakulását, és kedvez a szervezeti normák és standardok internalizálódásának. A fragmentált foglalkoztatási viszony kalkulatív, a munkavállalónak a fizetés mértéke a legfőbb prioritás. A konfliktusos foglalkoztatási viszony pedig azt a szervezeti kultúrát jelöli, ahol a munkavállalóknak nagy szerepük van a szervezeti kultúra létrehozásában és alakításában, viszont itt a hierarchikus kapcsolatokat a bizalmatlanság és a távolság jellemzi. A fogalmat a változó munkaerő-piaci dinamikák közepette 1989-ben revideálta Rousseau arra a tendenciára reflektálva, miszerint az írásba foglalt törvényes szerződések komplexitása és tartalma egyre növekszik a szerződések értelmezéseiből eredő konfliktusok elkerülésének érdekében. Rousseau (1989) kimondottan a munkavállaló egyéni pszichológiai szerződéséről ír elhatárolva azt a munkahelytöl, amely szerinte nem rendelkezhet pszichológiai szerződéssel. A pszichológiai szerződés a munkavállaló hiedelme a munkaszerződés feltételein túl a munkaadóhoz füződő kapcsolatában jelen lévő kölcsönös elvárásokról és kötelezettségekről, amiben jelentős szerepe van a szubjektivitásnak. Rousseau (1989) a munkáltató-munkavállaló kapcsolatot az eladó-kliens kapcsolathoz hasonlította, ami szolgáltatásorientált jellegű és folytatólagosságra törekvő. Az elméletben a hiedelmek nyíltan vállalt ígéretekből és a kapcsolatban adottnak feltételezett tényezőkből épülnek fel. A hiedelmek szubjektivitása az eltérő értelmezésekből, kognitív korlátokból, a referenciapontok divergenciájából és a kapcsolatok természetéből ered. Az elmélet a munkaadó-munkavállaló kapcsolatban a kölcsönös kötelezettségek létezését feltételezi. Rousseau a pszichológiai szerződést megkülönbözteti az elköteleződés fogalmától. Ha a munkavállaló elkötelezett a munkahelye felé, az nem feltétlenül jár együtt azzal, hogy a munkavállalónak a foglalkoztatottsági kapcsolatról olyan hiedelmei vannak, amelyek a kapcsolathoz kölcsönös kötelezettségeket társítanak. Másrészt egy elkötelezett munkavállaló elfogadja, és belsővé teszi a munkahelye értékeit és küldetését.
A pszichológiai szerződéshez ez nem feltétel. Rousseau (1989) elméletének gyökerei között megtalálhatók Argyris (1960), Schein (1965), Weick (1979), Adams (1965), MacNeil (1985), Adams és Freedman (1976) munkái. Rousseau hallgatólagos szerződésröl (implied contract) is ír, de a fogalom nem vált kutatásainak fókuszává. A hallgatólagos szerződés társas konszenzus eredménye, mások számára is megfigyelhető, a szervezeti kultúra és szabályok részéhez tartozik, a feleket a kölcsönös kötelezettségek teljesítéséhez tartja, és a kapcsolat szintjén, diádikusan vagy szervezetek között létezik.

\section{Mérési módszerek}

A pszichológiai szerződés tartalmának mérésére Rousseau és Tijoriwala (1998) tartalomorientált, jellemzőorientált, értékelésorientált módszert különböztetett meg. Azt találták, hogy a pszichológiai szerződés tartalmait az egyéni szerződéses elemekre fókuszálva lehet operacionalizálni, mert egy standard pszichológiai szerződés fogalom az egyéni változók megismerését akadályozná. Guest (1999) érvelése szerint az elméletet tudományos alapossággal a konstruktivista episztemológiából kiinduló kvalitatív kutatás lenne képes leírni, és megérteni, de ennek a kutatásnak az empirikus tesztelése elengedhetetlen. A Psychological Contract Inventory kérdőív Rousseau elméletén alapszik, és változóorientált megközelítést képvisel (Rousseau, 2000). Freese és Schalk (2008) négy mérőeszközt nevez meg (Freese \& Schalk, 1997; Psycones, 2005; Rousseau, 1990, 2000), amelyek több skálát tartalmaznak, mint amilyenek az észlelt szervezeti kötelességek skála, az észlelt munkavállalói kötelességek skála, a pszichológiai szerződés felbontása skála, a pszichológiai szerződésszegés skála, a pszichológiai szerződés teljesülését és megszegését globálisan felmérő skála. A skálák képesek együttesen mérni a pszichológiai szerződés tartalmát és értékelését, több nyelven használhatóak. Freese és Schalk (2008) tudománytalannak tartják, hogy megalkotható lenne egy standard kérdőív. Javasolják, hogy a pszichológiai szerződés konstruktumot mérhetősége érdekében elméletalapú nomológiai hálóba kell helyezni. Az egyéni észlelés mérése mellett érvelnek, mert metodológiailag a diádikus mérésnek nagyobb az esélye, hogy invalid eredményekre vezet. Ennek okai között szerepel, hogy nem szükségszerüen kommunikálja minden szervezet a munkavállalói elvárásokat. Ha ez mégis kimondva vagy leírva megtörténik, az elvárások több munkahelyi szereplőtől is érkezhetnek (Rousseau, 1995).

\section{Vizsgált jelenségek és a konceptuális rendszer}

Rousseau (1989, 1995) elméleteivel olyan jelenségeket vizsgáltak, mint a munkahelyi elégedettség, a munkavállalói hozzájárulás, a szervezeti elkötelezettség, a munkahelyi hanyagság, a munkahelyi deviancia, a munkahelyi bizonytalanság, az innovatív munkahelyi viselkedés, a munka-család konfliktus és a szervezeti kilépés okai (Hill, Morganson, Matthews \& Atkinson, 2016; Jiang, Chen, Sun \& Yang, 2017; Li \& Chen, 2018; Liang, 2019; Niesen, Van Hootegem, Vander Elst, Battistelli \& De Witte, 2018; Robinson \& Rousseau, 1994; Turnley \& Feldman, 1999). 
A mintavétel során különböző foglalkozású és különböző szervezeti formában dolgozó munkavállalókat vizsgáltak, mint például tűzoltókat, orvosokat, betegeket, ápolókat, tudásintenzív szolgáltató vállalatnál dolgozókat, bányászokat, táncmüvészeket, tehetségeket, pályakezdőket, informatikusokat, hátrányos helyzetü dolgozókat, köztisztviselőket (pl. Farnese, Livi, Barbieri \& Schalk, 2018; Kong \& Jolly, 2018; Tabor, Griep, Collins \& Mychasiuk, 2018; Topa \& Jurado-Del Pozo, 2018; Yang \& Wu, 2018; Wilkens \& Nermerich, 2010). A munkaszerződés esetében rugalmas munkaidőben dolgozók, otthoni munkavégzéssel dolgozók, határozott és határozatlan munkajogviszonnyal dolgozók, munkaszerződés nélkül dolgozók pszichológiai szerződéseinek leírására is történtek kísérletek (pl. Cooke, Hebson \& Carroll, 2004).

Számos pszichológiai szerződéstípust találunk a szakirodalomban, amiket tartalmuk különböztet meg. Kezdetben Rousseau (1990) a munkavállalók pszichológiai szerződésének tartalmát illetően hét elvárást és nyolc kötelezettséget talált. A munkavállalók elvárásai között szereplő tartalmak az előléptetés, jutalom, teljesítménybérezés, képzés, munkahelyi biztonság, karrierlehetőség, a humán erőforrás szakembereitől támogatás. A munkavállalók kötelezettségnek tartják a túlórázást, a lojalitást, a munkahelyi bevonódást, a tervezhetőséget, a belső munkaügyi szabályzat ismeretét, a munkahely érdekeihez való alkalmazkodást, az őszinteséget és legalább két év munkaviszony fenntartását. Herriot és munkatársai (1997) a kritikus esemény technikájával vizsgálták munkavállalók és munkaadók pszichológiai szerződésének tartalmát. A munkavállalói kötelességek hét kategóriáját (órák, munka, őszinteség, hüség, célok, önprezentáció, rugalmasság) és a szervezeti kötelességek tizenkét kategóriáját (tréning, igazságosság (kiválasztás, értékelés, előléptetés, kiléptetés), személyes és családi igények, konzultáció és kommunikáció, diszkréció, humánum, elismerés, környezet, igazság, fizetés, jutalmak, biztonság) különböztették meg. A munkavállalók hangsúlyozzák az alapvető egzisztenciális faktorokat, míg a szervezeti képviselők kapcsolati oldalról fogalmazzák meg elvárásaikat. A munkavállalói kötelezettségeknél az alkalmazottak többsége gyakrabban említette az önkifejezést, míg a szervezeti képviselők a szervezeti hüséget tartották legfontosabb szervezeti kötelezettségnek. A túlórázó dolgozók és az idősebb vezetők kevésbé helyeztek hangsúlyt az egzisztenciális biztonságra, és nagyobb szervezetnél kevésbé jelent meg az őszinteség mint elvárás. Rousseau (1990) szerint a fókusz, az időintervallum, a stabilitás, a kiterjedés, a megfoghatóság mentén két típusba csoportosíthatók a pszichológiai szerződések. A tranzakcionális pszichológiai szerződés (transactional psychological contract) rövid távú, gazdasági kötelezettségekre vonatkozik. A kapcsolati pszichológiai szerződés (relational psychological contract) nyitott végü, dinamikus, hosszú távú. Rousseau és Wade-Benzoni (1994) egyensúlyi és átmeneti munkaperiódushoz tartozó pszichológiai szerződéstípust írt le a munkaviszony időtartama és a munkahely munkavállalóval szemben támasztott teljesítményelvárása mentén. Az átmeneti pszichológiai szerződés esetében bizonytalan a munkavállaló jövője a munkahelyén, kevés a bizalma és általában maga a feladat is változó. Az egyensúlyi pszichológiai szerződés esetében hosszú távú, nagyobb fokú a bizalom és az elkötelezettség. Shore és Barksdale (1998) az egyensúly foka és a kötődés szintje alapján különböztetett meg kiegyensúlyozott és kiegyensúlyozatlan pszichológiai szerződéstípusokat. Bunderson (2001) az adminisztratív és a szakmai pszichológiai szerződést különböztette meg. Van den Brande et al. (2002) a hatalmi távolság és a szerződés szintje alapján kollektív és individuális pszichológiai szerződést neveztek meg. Hierarchia mentén szimmetrikus és aszimmetrikus pszichológiai szerződésekröl beszélhetünk (Thomas et al., 2010). Sels és munkatársai (2004) a pszichológiai szerződés hat változóját határozták meg, mint megfoghatóság, kiterjedés, stabilitás, időkeret, csere szimmetriája, szerződés szintje. A pszichológiai szerződés teljesítésének (psychological contract fulfillment), vagy megszegésének (psychological contract violation) észlelése a pszichológiai szerződés értékelése (Freese \& Schalk, 2008). A pszichológiai szerződés teljesítésének indikátorai a munkavállaló részéről lehet a munkahelyi elégedettség, szervezeti elköteleződés, szervezeti magatartás, szervezeti teljesítmény, újító viselkedés (Lester, Turnley, Bloodgood \& Bolino, 2002; Ramamoorty, Flood, Slatter \& Sardessai, 2005; Robinson \& Morrison, 1995). A pszichológiai szerződés megszegésének észlelését érzelmi tapasztalat kíséri (Rousseau, 1995). Guest (1998) szerint ennek alapja a vélt igazságtalanság érzete. Az érzelmi tapasztalatot érzelmi reakciók követhetik, ami attitüdváltozásban, viselkedésváltozásban is megjelenhet (Zagenczyk, Smallfield, Scott, Galloway \& Purvis, 2017; Zhao et al., 2007). Rousseau (1995) kutatási eredményei szerint a pszichológiai szerződés megszegését hanyagság, szakítás, becsapás válthatja ki. Erre adott reakció lehet kilépés, beszélgetés kezdeményezése, passzivitás, destruktivitás. Herriot és Pemberton (1997) definíciója implikálja a munkaadói perspektíva relevanciáját, aminek a vizsgálatát több kutató is szorgalmazta (Tsui, Pearce, Porter, \& Tripoli, 1997; Coyle-Shapiro \& Kessler, 2002; Guest \& Conway, 2002). A munkaadói oldal pszichológiai szerződésszegésekben betöltött fontosságára több kutató is felhívta a figyelmet (Tekleab \& Taylor, 2003; Masterson \& Stamper, 2003). A munkaadói perspektívában kulturális értékek, szervezeti kultúra, vezetési stílus, személyiségjellemzők is meghatározóak (Henderson, Wayne, Shore, Bommer, \& Tetrick, 2008; Cable, 2010; Zagenczyk et al., 2015; Yang \& Wu, 2018). A felettesek mellett a mentorok és szerepmodellek is befolyásolhatják a munkavállaló hiedelmeit a reciprocitásról, de az elvárások alakulásában releváns a szervezet toborzással kapcsolatos kommunikációja (Guest, 2002; Zagenczyk, Gibney, Kiewitz, \& Restubog, 2009). A munkavállaló pszichológiai szerződésének tartalmára ható munkaszerződésének és munkafeltételeinek formálására, újratárgyalására felettesével vagy felettesének közvetítésével képes. Ez függhet a szervezeti eljárásrendektől, HR-folyamatoktól (Laulié \& Tekleab, 2016). Mivel a kapcsolat aszimmetrikus, a felettesnek van nagyobb szerepe abban, hogy változik a munkaszerződés, és ezt ő hogyan kommunikálja a munkavállaló felé (Ba- 
ker, Gibbons \& Murphy, 1994). A szakirodalom többségében munkavállalókat vizsgáló tanulmányok vannak, amik a foglalkoztatottsági kapcsolatban előforduló diszfunkcionalitásokra, pszichológiai szerződésszegésre ( $p$ sychological contract violation) és szerződésbontásra ( $p$ sychological contract breach) fókuszálnak (Griep, Vantilborgh, Baillien \& Pepermans, 2018; Lester, Turnley, Bloodgood \& Bolino, 2002; Li \& Chen, 2018; Robinson, 1996; Zhao, Wayne, Glibkowski \& Bravo, 2007). Cégek között és csapatszinten definiált konstruktum is létezik (Gibbard et al., 2017; Kaulio, 2013; Laulié \& Tekleab, 2016).

\section{A foglalkoztatás alternatív mérésének példája}

Tsui et al. (1997) az elméletet a munkavállaló-szervezet kapcsolat kezelésének stratégiájához sorolja, ami a munkavállaló mellett a munkaadókat és a munkatársakat is implikálja a reciprocitás feltételezésével (Laulié \& Tekleab, 2016). A pszichológiai szerződéselméletek célja a munkaadó-munkavállaló kapcsolatának pszichológiai dimenziók mentén való leírása a foglalkoztatásra vonatkozóan, de az operacionalizálási és mérési kísérletek az elméletben a pszichológiai szerződés konstruktum ad hoc jellegü konceptualizálása miatt tudományosan megkérdőjelezhetőek (Guest, 1998b; Buxall \& Purcell, 2003). Továbbá a konstruktum eredményorientált szemléletet képvisel, nem akcióorientált (Cullinane \& Dundon, 2006). A szerződés megnevezés ellenére az elméletből fejlesztett mérőeszközök nem hatékony eljárások, mert nem mérik azokat a specifikus cselekvéseket, amelyek a változás eléréséhez szükségesek (Berne, 1966). A pszichológiai szerződések mérésének kutatási eredményeiben kimagasló a munkavállalói oldalról a munkahelyi kompetenciafejlesztés lehetősége mint elvárás, ezért a szerző a foglalkoztatás egy egyéni szintű kompetenciafókuszú mérőeszközét mutatja be, amely alkalmas arra, hogy megvizsgálja mind a munkavállaló, mind a munkaadó válaszát, és a két fél teszteredményének összehasonlításával értékelhetővé válnak a foglalkoztatásra vonatkozó konvergencia- és divergenciaszempontok. Van der Heijde és Van der Heijden (2006) fejlesztette ki a foglalkoztatás kompetenciaalapú, multidimenzionális mérőeszközét. A mintába a munkavállaló mellett a munkavállaló közvetlen felettesét is bevonták. A tesztfejlesztés tudományos elméletekre, a kompetencia mint koncepció interpretatív megközelítésére és feltáró kutatásra épült. A tesztfejlesztés eredményében öt dimenzó határozza meg a foglalkoztatást: szakértelem, proaktivitás a szakmai tevékenységben, piaci környezethez való alkalmazkodás, network-munkára való képesség, a munkavállalói és a munkaadói érdekek összeegyeztetésére való képesség.

\section{Diszkusszió}

Rousseau (1989) gondolatmenetét a koncepció leírásához a munkaszerződésben leírhatatlan, a foglalkoztatottsági kapcsolatot látensen befolyásoló tényezők vezették, amiben a munkavállalók megtartásának és motiválásának lehetséges eszközét látta. Terapeuta-páciens szerződés esetében is kapcsolati szabályozó a nem tudatos tartalmak.
Míg egy terapeutától szakmai elvárás, hogy ezeket a tartalmakat észrevegye a kapcsolat és páciense javára, addig a munkaadónak nem tartozik a kompetenciájába a munkakapcsolataiban jelenlévő nem tudatos tartalmak ismerete. Ebböl következhet, hogy a munkaadó-munkavállaló pszichológiai szerződés kutatásában a legnépszerübb azoknak a tényezőknek a vizsgálata, amelyek kiváltják a pszichológiai szerződések megszegését. Ezek a tényezők a kutatások eredményeiben a munkavállalók részéről visszatérően a fejlődésüket segítő munkaadói támogatás hiánya, a kompetenciafejlesztés lehetőségeinek hiánya, a munkahelyi tanulás és a karrierlehetőségek hiánya (pl. Koskina, 2013; Dries \& De Gieter, 2014). Az eredmények felhívják a figyelmet a felnőttképzés fontosságára. Az elvárásaikban csalódott munkavállalók kötődési stílusuktól függően reagálnak nem teljesült pszichológiai szerződésük észlelését követően (Schmidt, 2016). A kötődéselmélet értelmében a munkavállaló kötődési stílusa összefügg azzal, ahogyan a munkahelyén viselkedik, ahogyan interpretálja a helyzeteket, ahogy viszonyul másokhoz (Harms, 2011). Az elutasító-elkerülő kötődésű munkavállalóból nem vált ki erős érzelmeket a pszichológiai szerződés megszegése. A biztonságos kötődési stílusú munkavállaló esetében mérsékelt az érzelmi válasz, mert képes szétválasztani munkahelyi kapcsolatait személyes kapcsolataitól. A bizalmatlan-elkerülő kötődési stílusú munkavállaló nem csalódik, mert nem vár jót, így ezt is várja, és ezt is veszi észre. Nincsen erős érzelmi reakciója. A szorongó-aggodalmaskodó kötődési stílusú munkavállaló önelfogadása mások elfogadásától függ, gyakran túlteljesítenek, és a pszichológiai szerződésszegés több teljesítményre sarkallja őket (Schmidt, 2016). A tehetséges munkavállalók identitásérzetüket megerősítő folyamatban meghaladhatják pszichológiai szerződésüket, mert képességeik aktív alanyává válnak. Ennek a lehetőségét támasztják alá Wilkens és Nermerich (2010) eredményei. A magasan képzett és kimagasló teljesítményü dolgozók proaktívan keresik azokat a munkafeltételeket, amelyek szakmai fejlödésüket támogatják. Nem egy szervezet mellett köteleződnek el, hanem szakmai és személyes fejlődésük mellett folyamatosan új kereteket alkotnak, facilitálják saját öndeterminációjukat. Karrierútjuk során szakértelmükre építenek. Szakértelmük fejlesztésével önfoglalkoztatóvá érnek. Aspirációjuk megtartásához, növeléséhez a kockázatokat is vállalják.

A munkaszerződés az a forma, ami garanciát tud vállalni a munkakapcsolatban a munkavállaló számára. A pszichológiai szerződést nem védi semmi. Nem elvárható a munkaadótól a munkaszerződésben leírt feltételeken túl, hogy nem leírt elvárásokat teljesítsen, így nem is igazán értelmezhető a pszichológiai szerződés megszegése sem. Ha a munkavállalónak a munkaszerződésben nem szereplő elvárásai vannak a munkaadó felé, és a munkavállaló csalódik, inkább beszélhetünk nem reális, túlzó vagy illuzórikus elvárásokról (O’Meara, Bennett, \& Neihaus, 2016). Lewin (1972) elvárások helyett igényszintről beszél. Eszerint a munkavállaló munkahely felöl elvárt igényeit befolyásolják a múltbeli sikerei, a kudarcai, a munkahelyi csoportnormák, munkatársainak teljesítményei. Ha a 
munkavállaló nem jól méri fel a munkahelytől elvárható igényeket, vagy nincs elég önbizalma, a foglalkoztatási kapcsolat negatív irányba fordulhat, és ebben az esetben lehet jelentősége a pszichológiai szerződésszegésként leírt jelenségek vizsgálatának. A munkaszerződés mellett a foglalkoztatási kapcsolatokat szabályozó humánerőforrás-menedzsment és innovatív problémamegoldó gyakorlat képesek a munkavállaló és a munkaadó elvárásait összeegyeztetni (Guest \& Conway, 1998, 2002). A munkaadó és a munkavállaló kapcsolatszabályozásának a munkahelyi menedzsment befolyásán kívül eső pszichológiai következményeit a munkaszerződés társadalompszichológiai jellegének nevezhetjük (Dunlop, 1958). Ha a konstruktummal dolgozó jövőbeli kutatások megtervezésénél figyelembe veszik a kutatók a foglalkoztatási kapcsolatot befolyásoló kontextuális faktorokat, mint amilyenek a felek kapcsolatai, a partnerek erőforrásai, a lehetséges jövőbeli foglalkoztatási alternatívák elérhetősége és a foglalkoztatás szektor, a kutatások fösodrába került pszichológiai szerződések megszegéséről egzaktabb magyarázatot kaphatunk. Ennek hiányában a jövőbeli kutatási eredmények validitásáról, megbízhatóságáról és alkalmazhatóságáról korlátozottan beszélhetünk.

\section{Implikáció}

A Rousseau-féle pszichológiai szerződéselméletet számos kritika érte (Cullinane \& Dundon, 2006). Rousseau a munkavállaló motivációjára ható szocializáció fontosságát elismeri, de kutatásai a szervezetpszichológia eszköz- és fogalomrendszerén, zárt értékrendszeren belül maradnak (Baruch \& Rousseau, 2018). A pszichológiai szerződés tudományosan adekvát megnevezését is megkérdőjelezték (Guest, 1998a, 1998b, 2004; Boxall \& Purcell, 2003; Conway \& Briner, 2005). Guest (1998b) szerint a koncepció egy metaforának tekinthető. Ahogy a nyelvet magát is cselekvésnek tekinti, mert befolyásolja, ahogy gondolkodunk a világról, a pszichológiai szerződés nyelvezete a menedzsment retorikai eszközeivel él (Cullinane \& Dundon, 2006). Ha a menedzsment szemléletének emberképét vizsgáljuk, az feltételezi, hogy a kapcsolat a cserefolyamat müködéséig létezik. A munkakapcsolatot mozgató munkavállalói és munkaadói motivációnak a vizsgálatával adósak maradnak a Rousseau-t követő kutatók (Cullinane \& Dundon, 2006). Többségében a pszichológiai szerződésszegésekre adott munkavállalói reakciókat vizsgálták (Zagenczyk et al., 2017). Gibson (1966) elméletében a munkavállalói motiváció a hiedelem-értékrendszer müködése, és a pszichológiai szerződést közvetetten a társadalom, közvetlenül a munkahely és a munkavállaló közti csere tartja fent. Gibson bevezeti az autenticitást, ami a munkaidentifikáció célja lehet. A téma kezdeti kutatásai közül Gibson (1966) elmélete tudta meghaladni a humánerőforrás-menedzsment szemléletét. Eredetileg a pszichológiai szerződéselmélet a humánerőforrás-menedzsment gyakorlatából ered, arra építve alkalmazható mérési eljárásokat dolgoztak ki. A humánerőforrás-menedzsment az embert haszonszerző, racionális lénynek reprezentálja, így az egészségesen altruista emberkép meg se jelenhet
(Fromm, 2001). Thompson és Bunderson (2003) modellje se tudta ezt a hiátust áthidalni. Az ideológiai pszichológiai szerződéselmélet nem magyarázza pl. az ideológiai önigazolás jelenségét, a munkaadók és munkavállalók önszabályozását. Az ideológiai pszichológiai szerződés koncepció értelmében minden szervezet a szervezeti kultúra részéhez tartozó ideológiai alapokkal müködik. Ha a szervezetnek az ideológiájában a proszociális értékeknek prioritásuk van, és ha az együttműködésre irányuló intrinzik motivációval rendelkezik a munkaadó és a munkavállaló is, az identitásuk megerősödéséhez vezethet (Berne, 1966). Az együttmüködésben intrinzik motiváció lehet az elköteleződés a hivatásértékekhez, elköteleződés a munkához és szakmai fejlődéshez (McCabe \& Sambrook, 2013; Millward \& Hopkins, 1998). Ez kölcsönösen önmegerősítő folyamat, nem harmadik fél kényszeríti ki. A folyamatot önmegerősítő vagy kapcsolati szerződésként is definiálták (Baker, Gibbons \& Murphy, 2002). A pszichológiai szerződéshez társított implicit kifejezés konnotációja valami meghatározhatatlanra, bizonytalanra utal, ami nem is érthető meg (Baker et al., 2002). A közgazdaságtanban az implicit szerződés terminus a piac kiszámíthatatlanságára utal (Rosen, 1985). Ugyanakkor a kapcsolati szerződés kifejezés paradoxont rejt magában a tekintélyelvü szemlélet miatt (Semjén, 2017). A szerződés jogi eredetének feltételezése esetén a szerződés léte hierarchikus viszonyok létezésére következtet, a hierarchiát a hatalmi különbség definiálja, ami két fél együttműködésében az intrinzik motivációt kiszoríthatja, ha külső ösztönzőként jelenik meg, és az együttműködést túlzott büntetéssel vagy túlzott jutalmazással kényszeríti ki. Cameron és Pierce (1999) szerint a jutalom növelése nem minden esetben csökkenti az intrinzik motivációt. Ha motivált egyetemi hallgatók lehetőséget kapnak szakmai fejlődésre az egyetemtől és az oktatóktól, a tanulásra irányuló törekvés mint intrinzik motiváció fokozódik (Koskina, 2013). Ha tehetséges munkavállalók szakmai fejlődési lehetőségek hiányában magas elvárásokat tapasztalnak a munkaadótól, frusztrációt eredményez, ami az intrinzik motivációt nem, de a céggel szembeni elköteleződést gátolja (Dries \& De Gieter, 2014). A paradoxon feloldható a jogi formula integrálásával, ha a szerződés eredetének a morális kötelezettséget tekintjük (Maine, 1906). Ebben az esetben a kapcsolati alapelv a kapcsolati etika lesz (Weber, 1995).

\section{Felhasznált irodalom}

Adams, J. S. (1965). Inequity in Social Exchange. In Berkowitz, L. (Ed.), Advances in Experimental Social Psychology (pp. 267-299). New York: Academic Press. https://doi.org/10.1016/S0065-2601(08)60108-2

Adams, I.S., \& Freedman, S. (1976). Equity Theory Revisited; Comments and Annotated Bibliography. In Berkowitz L., Walster, E. (Eds.), Adtonces in Experimental Social Psychology (pp. 43-90). New York: Academic Press. https://doi.org/10.1016/S0065-2601(08)60058-1

Argyris, C. (1960). Understanding Organizational Behavior. Homewood: Dorsey Press. 
Baker, H. (1985). The unwritten contract: job perceptions. Personnel Journal, 64, 36-41.

Baker, G., Gibbons, R., \& Murphy, K. (1994). Subjective performance measures in optimal incentive contracts. Quarterly Journal of Economics, 109(4). 1125-1156. https://doi.org/10.2307/2118358

Baker, G., Gibbons, R., \& Murphy, K. (2002). Relational contracts and the theory of the firm. The Quarterly Journal of Economics, 117(1), 39-84. https://doi.org/10.1162/003355302753399445

Baruch, Y., \& Rousseau, D. (2019). Integrating psychological contracts and ecosystems in career studies and management. Academy of Management Annals, 13 (1), 84-111. https://doi.org/10.5465/annals.2016.0103

Berne, E. (1966). Principles of Group Treatment. Oxford: Oxford University Press.

Blau, P. (1964). Exchange and Power in Social Life. New York, NY: Wiley.

Bunderson, J.S. (2001). How work ideologies shape the psychological contracts of professional employees: Doctor's responses to perceived breach. Journal of Organizational Behavior, 22(7), 717-741. https://doi.org/10.1002/job.112

Boxall, P., \& Purcell, J. (2003). Strategy and Human Resource Management. Basingstoke: Palgrave Macmillan.

Cameron, J., \& Pierce, D. (1999). Effects of reward on intrinsic motivation-Negative, neutral, and positive: Comment on Deci, Koestner, and Ryan. Psychological Bulletin, 125(6), 677-691. https://doi.org/10.1037/0033-2909.125.6.677

Conway, N., \& Briner, R. (2002). A daily diary study of affective responses to psychological contract breach and exceeded promises. Journal of Organisational Behavior, 23, 287-302. https://doi.org/10.1002/job.139

Conway, N., \& Briner, R. (2005). Understanding Psychological Contracts at Work - A Critical Evaluation of Theory and Research. New York, NY: Oxford University Press.

Cooke, F., Hebson, G., \& Carroll, M. (2004). Commitment and Identity Across Organizational Boundaries. In Marchington, M., Grimshaw, D., Rubery, J., \& Willmott, H. (Eds.), Fragmenting Work: Blurring Organizational Boundaries and Disordering Hierarchies (pp. 179-198). Oxford: Oxford University Press

Coyle-Shapiro, J., \& Kessler, I. (2002). Exploring reciprocity through the lens of the psychological contract: employee and employer perspectives. European Journal of Work Organisational Psychology, 11(1), 69-86. https://doi.org/10.1080/13594320143000852

Coyle-Shapiro, J., Costa, S., Doden, W., \& Chang C. (2019). Psychological contracts: past, present, and future. Annual Review of Organizational Psychology and Organizational Behavior, 6 (1), 145-169. https://doi.org/10.1146/annurev-orgpsych-012218-015212
Cullinane, N., \& Dundon, T. (2006). The psychological contract: a critical review. International Journal of Management Reviews, 8(2), 113-129.

https://doi.org/10.1111/j.1468-2370.2006.00123.x

De Ruiter, M., Schalk, R., \& Blomme, R.-J. (2016). Manager responses to employee dissent about psychological contract breach: a dyadic process approach. Management Communication Quarterly, 30(2), 188-217.

https://doi.org/10.1177/0893318915623238

Dries, N., De Gieter, S. (2014). Information asymmetry in high potential programs: A potential risk for psychological contract breach. Personnel Review, 43(1), 136-162.

https://doi.org/10.1108/PR-11-2011-0174

Dunlop, J. (1958). Industrial Relations Systems. New York, NY: Holt \& Co.

Farnese, M.L., Livi, S., Barbieri, B., \& Schalk, R. (2018). You can see how things will end by the way they begin: The contribution of early mutual obligations for the development of the psychological contract. Frontiers in Psychology, 9, 543.

https://doi.org/10.3389/fpsyg.2018.00543

Freese, C., \& Schalk, R. (1997). Tilburgse Psychologisch Contract Vragenlijst [Tilburg Psychological Contract Questionnaire]. Tilburg: Tilburg University.

Freese, C., \& Schalk, R. (2008). How to measure the psychological contract? A critical criteria-based review of measures. South African Journal of Psychology, 38(2), 269-286. https://doi.org/10.1177/008124630803800202

Fromm, E. (2010). Utak egy egészséges társadalom felé. Budapest: Napvilág Kiadó.

Gibbard, K., Griep, Y., De Cooman, R., Hoffart, G., Onen, D., \& Zareipour, H. (2017). One big happy family? Unraveling the relationship between shared perceptions of team psychological contracts, person-team fit and team performance. Frontiers in Psychology, 8, 1966. https://doi.org/10.3389/fpsyg.2017.01966

Gibson, R. (1966). Toward a conceptualization of absence behavior of personnel in organization. Administrative Science Quarterly, 11(1), 107-133. https://doi.org/ 10.2307/2391396

Griep, Y., Vantilborgh, T., Baillien, E., \& Pepermans, R. (2016). The mitigating role of leader-member exchange when perceiving psychological contract violation: a diary survey study among volunteers. European Journal of Work Organisational Psychology, 25(2), 254-271. https://doi.org/10.1080/1359432X.2015.1046048

Guest, D.E. (1998a). Is the psychological contract worth taking seriously? Journal of Organizational Behavior, 19, 49-64. https://doi.org/10.1002/(SICI)10991379(1998)19:1+<649::AID-JOB970>3.0.CO;2-T

Guest, D.E. (1998b). On meaning, metaphor and the psychological contract: A response to Rousseau (1998). Journal of Organizational Behavior, 19(special issue), 673-677. Retrieved from https://www.jstor.org/ stable/3100283 
Guest, D.E., \& Conway, N. (1998). Fairness at Work and The Psychological Contract. London: Institute of Personnel and Development.

Guest, D.E., \& Conway, N. (2002). Communicating the psychological contract: an employer perspective. Human Resource Management Journal, 12(2), 22-38. https://doi.org/10.1111/j.1748-8583.2002.tb00062.x

Guest, D.E. (2004). The psychology of the employment relationship: an analysis based on the psychological contract. Applied Psychology, 53(4), 541-555. https://doi.org/10.1111/j.1464-0597.2004.00187.x

Harms, P.D. (2011). Adult attachment styles in the workplace. Human Resource Management Review, 21(4), 285-296.

https://doi.org/10.1016/j.hrmr.2010.10.006

Henderson, D.J., Wayne, S.J., Shore, L.M., Bommer, W.H., \& Tetrick, L.E. (2008). Leader-member exchange, differentiation, and psychological contract fulfillment: A multilevel examination. Journal of Applied Psychology, 93(6), 1208-1219. https://doi.org/10.1037/a0012678

Heidrich, B. (2013). Alkalmazottak vezetése. Retrieved from https://www.tankonyvtar.hu/hu/tartalom/ tamop412A/0007_e6_alkalmazotti_vezetes_scorm/ pszichologiai_szerzodes_sP53RFmnOM6GXJT2.html

Herriot, P., \& Pemberton, C. (1997). Facilitating new deals. Human Resource Management Journal, 7(1), 45-56.

Herriot, P., Manning, W.E.G., \& Kidd, J.M. (1997). The content of the psychological contract. British Journal of Management, 8(2), 151-162.

https://doi.org/10.1111/1467-8551.0047

Hill, R.T., Morganson, V.J., Matthews, R. A., \& Atkinson, T. P. (2016). LMX, breach perceptions, work-family conflict, and well-being: a mediational model. The Journal of Psychology, 150(1), 132-149.

https://doi.org/10.1080/00223980.2015.1014307

Jardat, R. (2012). Denise versus Jean-Jacques: Homonymies, homologies and tectonic faults between psychological contract and social contract. Society and Business Review, 7(1), 34-49.

https://doi.org/10.1108/17465681211195779

Jiang, H., Chen, Y., Sun, P., \& Yang, J. (2017). The relationship between authoritarian leadership and employees' deviant workplace behaviors: the mediating effects of psychological contract violation and organizational cynicism. Frontier in Psychology, 8,732 . https://doi.org/10.3389/fpsyg.2017.00732

Kaulio, M. (2013). A psychological contract perspective on $R \& D$ alliance projects: Learning from a close-tofailing case. No 2013/3, INDEK Working Paper Series, Royal Institute of Technology, Department of Industrial Economics and Management. Retrieved from https:// EconPapers.repec.org/RePEc:hhs:kthind:2013_003

Kong, D.T., \& Jolly, P.M. (2018). A stress model of psychological contract violation among ethnic minority employees. Cultural Diversity and Ethnic Minority Psychology. 25(3), 424-438.

http://dx.doi.org/10.1037/cdp0000235
Koskina, A. (2013). What does the student psychological contract mean? Evidence from a UK business school. Studies in Higher Education, 38(7), 1020-1036. https://doi.org/10.1080/03075079.2011.618945

Kotter, J.P. (1973). The psychological contract: managing the joining-up process. California Management Review, 15(3), 91-99. https://doi.org/10.2307/41164442

Laulié, L., \& Tekleab, A.G. (2016). A multi-level theory of psychological contract fulfillment in teams. Group \& Organization Management, 41(5), 658-698.

https://doi.org/10.1177/1059601116668972

Lester, S.W., Turnley, W.H., Bloodgood, J.M., \& Bolino, M.C. (2002). Not seeing eye to eye: differences in supervisor and subordinate perceptions of and attributions for psychological contract breach. Journal of Organizational Behavior, 23(1), 39-56. https://doi.org/10.1002/job.126

Levinson, H., Price, C., Munden, K., Mandl, H., \& Solley, C. (1962). Men, Management and Mental Health. Cambridge, MA: Harvard University Press.

Lewin, K. (1972). A mezőelmélet a társadalomtudományban: válogatott elméleti tanulmányok. Budapest: Gondolat Kiadó.

Li, S., \& Chen, Y. (2018). The relationship between psychological contract breach and employees' counterproductive work behaviors: the mediating effect of organizational cynicism and work alienation. Frontiers in Psychology, 9, 1273. https://doi.org/10.3389/fpsyg.2018.01273

Liang, H.-L. (2019). Are emotions transmitted from work to family? A crossover model of psychological contract breach. Psychological Reports, 122(1), 288-304. https://doi.org/10.1177/0033294117750630

Maine, H.S. (1906). Ancient Law. London: John Murray.

Mccabe, T., \& Sambrook, S. (2013). Psychological contracts and commitment amongst nurses and nurse managers: A discourse analysis. International Journal of Nursing Studies, 50(7), 954-67.

https://doi.org/10.1016/j.ijnurstu.2012.11.012

Macneil, I. (1985). Relational contract what we do and do not know. Wisconsin Law Review, 4, 483-526.

Masterson, S.S., \& Stamper, C.L. (2003). Perceived organizational membership: an aggregate framework representing the employee-organization relationship. Journal of Organizational Behavior, 24(5), 473-490. https://doi.org/10.1002/job.203

Menninger, W.C., \& Levinson, H. (1954). Industrial mental health: some observations and trends. Menninger Quarterly, 8(4), 1-31.

Menninger, K. (1958). Theory of Psychoanalytic Technique. New York: Basic Books, Inc.

Millward, L.J., \& Hopkins, L.J. (1998). Psychological contracts, organizational and job commitment. Journal of Applied Social Psychology, 28(16), 1530-1556. https://doi.org/10.1111/j.1559-1816.1998.tb01689.x

Morrison, E., \& Robinson, S. (1997). When employees feel betrayed: a model of how psychological contract violation develops. Academy of Management Review, 22(1), 226-256. https://doi.org/10.5465/amr.1997.9707180265 
Nicholson, N., \& Johns, G. (1985). The absence culture and psychological contract-who's in control of absence? Academy of Management Review, 10(3), 397-407. https://doi.org/10.5465/amr.1985.4278945

Niesen, W., Van Hootegem, A., Vander Elst, T., Battistelli, A., \& De Witte, H. (2018). Job insecurity and innovative work behaviour: A psychological contract perspective. Psychologica Belgica, 57(4), 174-189. https://doi.org/10.5334/pb.381

O’Meara, K., Bennett, J.C., \& Neihaus, E. (2016). Left Unsaid: The Role of Work Expectations and Psychological Contracts in Faculty Careers and Departure. The Review of Higher Education, 39(2), 269-297. https://doi.org/10.1353/rhe.2016.0007

Portwood, J., \& Miller, E. (1976). Evaluating the psychological contract: its implications for employee job satisfaction and work behavior. Academy of Management Proceedings, vol. 1976 (1), 109-113. https://doi.org/10.5465/ambpp.1976.4975635

Psycones (2005). Retrieved from www.uv.es $\sim$ psycon

Ramamoorthy, N., Flood, P., Slatter, T., \& Sardessai, R. (2005). Determinants of innovative work behavior: development and test of an integrated model. Creativity and Innovation, 14(2), 115-128.

https://doi.org/10.1111/j.1467-8691.2005.00334.x

Robinson, S. (1996). Trust and breach of the psychological contract. Administrative Science Quarterly, 41(4), 574-599. https://doi.org/10.2307/2393868

Robinson, S., \& Rousseau, D. (1994). Violating the psychological contract: Not the exception but the norm. Journal of Organizational Behavior, 15(3), 245-259. https://doi.org/10.1002/job.4030150306

Rosen, S. (1985). Implicit contracts: A survey. Journal of Economic Literature, 23(3), 144-175. https://doi.org/10.3386/w1635

Rousseau, D. (1989). Psychological and implied contracts in organizations. Employee Responsibilities and Rights Journal, 2, 121-139. https://doi.org/10.1007/BF01384942

Rousseau, D. (1990). New hire perceptions of their own and their employer's obligations: a study of psychological contracts. Journal of Organizational Behavior, 11(5), 389-400. https://doi.org/10.1002/job.4030110506

Rousseau, D., Wade-Benzoni, K. (1994). Linking strategy and human resource practices: How employee and customer contracts are created. Human Resource Management, 33(3), 463-489.

https://doi.org/10.1002/hrm.3930330312

Rousseau, D. (1995). Psychological Contracts in Organizations: Understanding Written and Unwritten Agreements. Thousand Oaks: Sage.

Rousseau, D., \& Tijoriwala, S.A. (1998). Assessing psychological contracts: issues, alternatives and measures. Journal of Organizational Behavior, 19(51), 679-695. https://doi.org/10.1002/(SICI)10991379(1998)19:1+<679::AID-JOB971>3.0.CO;2-N
Rousseau, D. (2000). Psychological Contract Inventory (Technical Report). Pittsburgh, PA: Carnegie Mellon University.

Schein, E.H. (1965, 1988). Organizational Psychology. Englewood Cliffs: Prentice Hall.

Schein, E.H. (1985). Organizational Culture and Leadership. San Francisco: Jossey-Bass.

Schmidt, G. (2016). How adult attachment styles relate to perceived psychological contract breach and affective organizational commitment. Employee Responsibility and Rights Journal, 28, 147-170.

https://doi.org/10.1007/s10672-016-9278-9

Sels, L., Janssens, M., \& Van Den Brande, I. (2004). Assessing the nature of psychological contracts: a validation of six dimensions. Journal of Organizational Behavior, 25(4), 461-488.

https://doi.org/10.1002/job.250

Semjén, A. (2017). Az adózói magatartás különféle magyarázatai. Közgazdasági Szemle, 64(2), 140184.

http://dx.doi.org/10.18414/KSZ.2017.2.140

Shore, L., \& Barksdale, K. (1998). Examining degree of balance and level of obligation in the employment relationship: a social exchange approach. Journal of Organizational Behavior, 19(51), 731-744. https://doi. org/10.1002/(SICI)1099-1379(1998)19:1+<731::AIDJOB969>3.0.CO;2-P

Tabor, J., Griep, Y., Collins, R., \& Mychasiuk, R. (2018). Investigating the neurological correlates of workplace deviance using a rodent model of extinction. Scientific Reports, 8(1), 17316. https://doi.org/10.1038/s41598-018-35748-y

Tekleab, A.G., \& Taylor, M.S. (2003). Aren't there two parties in an employment relationship? Antecedents and consequences of organization-employee agreement on contract obligations and violations. Journal of Organizational Behavior, 24(5), 585-608. https://doi.org/10.1002/job.204

Thomas, D., Fitzsimmons, S., Ravlin, E., Au, K., Ekelund, B., \& Barzantny, C. (2010). Psychological contracts across cultures. Organization Studies, 31(11), 14371458. https://oi.org/10.1177/0170840610380811

Thompson, J., \& Bunderson, J. (2003). Violations of principle: Ideological currency in the psychological contract. The Academy of Management Review, 28(4), 571-586. https://doi.org/10.5465/amr.2003.10899381

Topa, G., \& Jurado-Del Pozo, J.F. (2018). Emotional exhaustion and health complaints as indicators of occupational diseases among civil servants in Spain. Journal of Clinical Medicine, 7(12), 523. https://doi.org/10.3390/jcm7120523

Tsui, A., Pearce, J., Porter, L., \& Tripoli, A. (1997). Alternative approaches to the employee-organization relationship: does investment in employees pay off? The Academy of Management Journal, 40(5), 10891121. https://doi.org/10.5465/256928 
Turnley, W., \& Feldman, D. (1999). The impact of psychological contract violations on exit, voice, loyalty, and neglect. Human Relations, 52(7), 143-156. https://doi.org/10.1177/001872679905200703

Van Den Brande, I., Sels, L., Janssens, M., \& Overlaet, R. (2002). Assessing the Nature of Psychological Contracts: Conceptualization and Measurement. DTEW Research Report 0241. 1-32. Retrieved from https://lirias.kuleuven.be/1766148?limo $=0$

Van Der Heijde, C., \& Van Der Heijden, B. (2006). A competence-based and multidimensional operationalization and measurement of employability. Human Resource Management, 45(3), 449-476. https://doi.org/10.1002/hrm.20119

Weber, M. (1995). A protestáns etika és a kapitalizmus szelleme. Budapest: Cserépfalvi Könyvkiadó.

Weick, K. E. (1979). The Social Psychology of Organizing. New York: McGraw-Hill.

Wilkens, U., \& Nermerich, D. (2011). Love it, change it, or leave it - Understanding highly-skilled flexible workers' job satisfaction from a psychological contract perspective. Management Revue, 22(1), 65-83. Retrieved from https://www.jstor.org/stable/41783671

Yang, T., \& Wu, Y. (2018). A study on the influence of patient participation on patient trust-based on sample survey in China. Frontiers in Psychology, 9, 2189.

https://doi.org/10.3389/fpsyg.2018.02189

Zagenczyk, T., Gibney, R., Kiewitz, C., \& Restubog, S.L. (2009). Mentors, supervisors and role models: do they reduce the effects of psychological contract breach? Human Resource Management Journal, 19(3), 237-259. https://doi.org/10.1111/j.1748-8583.2009.00097.x

Zagenczyk, T., Cruz, K., Cheung, J., Scott, K., Kiewitz, C., \& Galloway, B. (2015). The moderating effect of power distance on employee responses to psychological contract breach. European Journal of Work and Organizational Psychology, 24(6), 853-865.

https://doi.org/10.1080/1359432X.2014.961432

Zagenczyk, T., Smallfield, J., Scott, K., Galloway, B., \& Purvis, R. (2017). The moderating effect of psychological contract violation on the relationship between narcissism and outcomes: An application of trait activation theory. Frontiers in Psychology, 8, 1113. https://doi.org/10.3389/fpsyg.2017.01113

Zhao, H., Wayne, S., Glibkowski, B., \& Bravo, J. (2007). The impact of psychological contract breach on work-related outcomes: a meta-analysis. Personnel Psychology, 60(3), 647-680.

https://doi.org/10.1111/j.1744-6570.2007.00087.x 